\title{
Geometric analysis of injection-molded polymer gears (Rapid communication)
}

\author{
Jadwiga Pisula ${ }^{1)}$ (ORCID ID 0000-0002-3197-9528) \\ DOI: dx.doi.org/10.14314/polimery.2021.1.8
}

\begin{abstract}
Properties of polymer gears were tested using coordinate measurement methods. This study is a follow-up to research on geometric accuracy of gears manufactured by injection molding. Spur gears were measured on a coordinate measuring machine running the GINA software by Klingelnberg. Measurement results were output in the form of measurement sheets which included values required in the DIN 3962 standard. The article also analyses the topography of test gear teeth. The topography was presented for a single tooth of the gear and determined on the basis of the measurements of 9 profiles distributed evenly over a specific profile assessment interval (interval L $\alpha$ defined in the standard) and 7 tooth traces located within a relevant tooth trace assessment interval (interval L $\beta$ defined in the standard). All gears tested in this study were placed outside accuracy class 12.
\end{abstract}

Keywords: geometric accuracy, gear topography, molding shrinkage, polymer gears.

\section{Analiza geometryczna polimerowych kół zębatych otrzymanych metodą wtryskiwania}

Streszczenie: Właściwości użytkowe polimerowych kół zębatych badano z zastosowaniem współrzędnościowych metod pomiarowych. Opracowanie stanowi kontynuację prac nad dokładnością geometrii kół wytwarzanych metodą wtryskiwania. Do pomiaru kół zębatych walcowych użyto współrzędnościowej maszyny pomiarowej wyposażonej w specjalistyczne oprogramowanie o nazwie GINA firmy Klingelnberg. Wyniki pomiaru otrzymywano w postaci arkuszy pomiarowych uwzględniających wartości z normy DIN 3962. Analizowano również topografię zębów kół badawczych. Przedstawiono topografię jednego zęba koła, określoną na podstawie pomiaru 9 zarysów równomiernie rozmieszczonych na odpowiednim odcinku oceny zarysu (odcinku L $\alpha$ definiowanym wg normy) i 7 liniach zęba umiejscowionych na odpowiednim odcinku oceny linii zęba (odcinku L $\beta$ definiowanym wg normy). Wszystkie badane koła znalazły się poza 12 klasą dokładności.

Słowa kluczowe: dokładność geometryczna, topografia kół zębatych, skurcz przetwórczy, polimerowe koła zębate.

The recent years have seen rapid development of polymer materials, which are applied in manufacturing machine parts, including parts of gear-based drive systems. Such parts are manufactured on a large scale from structural polymers in a PA (polyamide), POM (polyoxymethylene), PC (polycarbonate) or ABS (acrylonitrile butadiene styrene) matrix using plastic working (injection molding) [1,2] or subtractive manufacturing methods (machining, electrical discharge machining) on numerically-controlled machine tools (milling with the use of a hobbing machine, slot cutter, profile cutter,

\footnotetext{
1) Rzeszow University of Technology, Department of Mechanical Engineering, Faculty of Mechanical Engineering and Aeronautics, al. Powstańców Warszawy 8, 35-959 Rzeszów, Poland.

e-mail: jpisula@prz.edu.pl
}

CNC-milling by cutting out tooth profiles) and electric discharge machines [3-5]. The injection molding technology allows us to obtain even several hundreds pieces in a single injection cycle, depending on the number of cavities in the mold (the greater number of cavities, the more cost-effective the production). Unfortunately, various undesirable phenomena (e.g. a rapid pressure drop in the mold) occurring in the injection molding process may cause defects in the molded pieces. Such defects include sink marks, air pockets, warping or the deterioration of dimensional accuracy. The geometric accuracy of the manufactured gears affects the operation of the gears in terms of uniformity of motion transmission and its strength, especially in terms of fatigue strength and wear. The present study is a continuation of research conducted in the Department of Machine Design at Rzeszów University of Technology on the geometric accuracy of polymer gears $[1,2,6]$, which are subjected to fatigue tests 
T a b l e 1. Plastic drying and injection process parameters

\begin{tabular}{|c|c|c|c|c|c|c|}
\hline Polymer material & P1 & $\mathrm{P} 2$ & P3 & $\mathrm{P} 4$ & P5 & P6 \\
\hline Drying time, $\mathrm{h}$ & $2-4$ & $2-4$ & $2-4$ & $2-4$ & $2-6$ & $6-8$ \\
\hline Drying temperature, ${ }^{\circ} \mathrm{C}$ & 80 & 80 & 80 & 80 & 80 & 100 \\
\hline Permissible humidity, \% & 0.1 & 0.2 & 0.2 & 0.2 & 0.12 & 0.1 \\
\hline Injection $\min / \max$ temperature, ${ }^{\circ} \mathrm{C}$ & $230-270$ & $280-300$ & $280-290$ & $285-305$ & $280-300$ & $320-330$ \\
\hline Mold min/max temperature, ${ }^{\circ} \mathrm{C}$ & $60-80$ & $50-90$ & $70-120$ & $70-120$ & $80-120$ & $140-180$ \\
\hline
\end{tabular}

in order to determine the mechanical properties of the gears made by various technologies.

\section{EXPERIMENTAL PART}

\section{Materials}

- Zytel PLS95G50DH2 BK261(PA66+45\%FG, polyamide $66+45 \mathrm{wt} \%$ of fiber glass) by DuPont, referred to as P1;

- Zytel HTN51G35HSL NC010 (PPA6+35\%FG, performance polyamide $6+35$ wt \% of fiber glass) by DuPont, referred to as P2;

- Zytel PLS95G35DH1 BK549 (PA66+35\%FG) by DuPont, referred to as P3; P4;

- Zytel 101L NC010 (PA66) by DuPont, referred to as

- Tarnamid T-27 NATUR (PA6) by Azoty Tarnów, referred to as $\mathrm{P} 5$;

- Grivory HTV-3H1 BLACK 9205 (PPA6+30\%FG) by ES CHEMIE AG, referred to as P6.

\section{Molding method used in the study}

Molded pieces were made using the injection molding technology on an injection molding machine by ENGEL. Before injection, the materials were dried in order to remove humidity which may cause defects in molded pieces in the process and lead to erroneous results. The exact parameters of the injection process constitute proprietary information. Table 1 shows parameters of the drying process as well as injection and mold temperatures.

\section{Key specifications of test gears}

The selected geometric data of the basic gears are given in Table 2.

$\mathrm{T}$ a b l e 2. Parameters of gears used in geometric accuracy tests

\begin{tabular}{l|c|c}
\multicolumn{1}{c|}{ Parameter } & Driving gear & Driven gear \\
\hline Number of teeth & 17 & 25 \\
\hline Pressure angle, deg & \multicolumn{2}{|c}{20} \\
\hline Module, mm & \multicolumn{2}{|c}{3} \\
\hline Centre distance, mm & \multicolumn{2}{|c}{63.292} \\
\hline Face width, mm & 56.990 & 81.584 \\
Outside diameter, mm & 4.712 & 4.717 \\
Tooth thickness, mm & & 15 \\
\hline
\end{tabular}

\section{Geometric accuracy measurement of molded gears}

Gear measurements were made on coordinate measuring machine P40 by Klingelnberg at the Gear Testing Laboratory at the Faculty of Machine Engineering and Aeronautics, Rzeszów University of Technology. GINA, a specialist software for spur gear measurement by Klingelnberg, was applied to make measurements and generate results in the form of measurement sheets. Measurements were taken in laboratory conditions at the temperature from $18^{\circ} \mathrm{C}$ to $20^{\circ} \mathrm{C}$ and low constant humidity. A rod with two ruby tips of diameter $1.5 \mathrm{~mm}$ each was used, offering shortest possible reach (Fig. 1). During the measurement, two reference bases of choice were used (cylindrical and face surface). The gears were placed in a three-jaw chuck in the centre point of the rotary table of the P40 coordinate measuring machine.

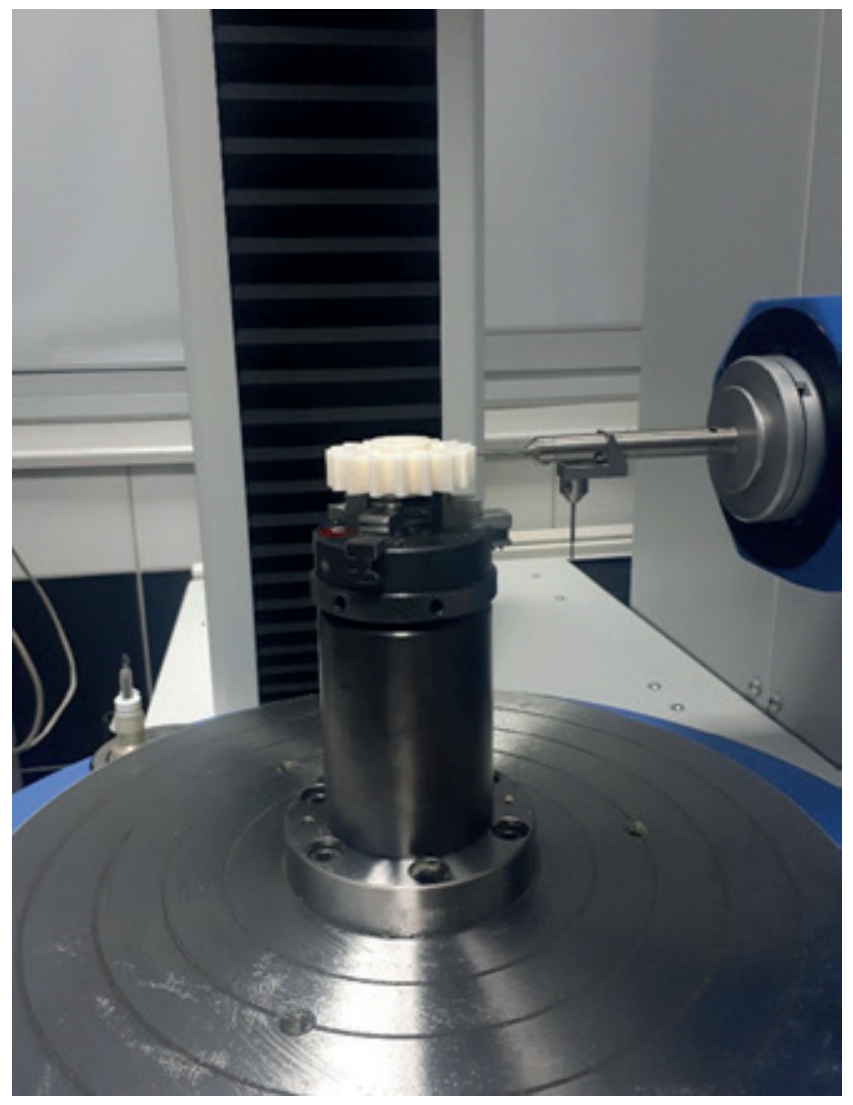

Fig. 1. Overview of the test station 


\section{RESULTS AND DISCUSSION}

Measurements on the P40 coordinate measuring machine were performed in order to determine the geometric accuracy of test gears. Sample results from measurement sheets are shown in Figs. 2-4 for a selected test gear made from P5. Measurement sheets contain parameters describing tooth profile and tooth trace geometry, pitch and tooth thickness. Tooth topography, defined by the size of profiles and tooth traces distributed evenly over the tooth width and height, was also assessed. The results of the analysis of the geometry of polymer gears are shown in Table 3.

Parameters contained in Table 3 describe tooth profile and trace geometry, pitch and tooth thickness. These include: $\mathrm{f}_{\mathrm{H} \alpha}$ - profile slope deviation, $\mathrm{F}_{\alpha}$ - total profile deviation, $\mathrm{f}_{\mathrm{f} \alpha}-$ profile form deviation, $\mathrm{f}_{\mathrm{H} \beta}$ - tooth trace slope deviation, $F_{\beta}$ - total tooth trace deviation, $\mathrm{f}_{\mathrm{f} \beta}$ - tooth trace form deviation, $\mathrm{f}_{\mathrm{pmax}}-$ max. single pitch deviation, $\mathrm{f}_{\text {umax }}$ - max. tooth spacing (pitch) error, $\mathrm{F}_{\mathrm{p}}$ - total cumulative pitch deviation, $\mathrm{F}_{\mathrm{pz} / 8}$ - cumulative pitch-span deviation for eight teeth, $\mathrm{F}_{\mathrm{r}}$ - runout error, $\mathrm{R}_{\mathrm{s}}$ - tooth thickness variation.

The values of the above parameters were used to determine the accuracy class of the geometric components of polymer gears and, ultimately, the gear's accuracy class. It should be emphasized that the accuracy class determined for at least one accurate parameter characterizing gear teeth is, at the same time, the gear's accuracy class. On the basis of results of the test gear measurements listed in Table 3, all gears are above accuracy class 12. An analysis of the results of gear profile measurements led to the conclusion that gear P3 attained profile accuracy class 10 for the left tooth flank, and accuracy class 12 for the right tooth flank. Profiles of the remaining polymer gears were outside the 12th accuracy class. Test results (Figs. 2-5, Table 3), i.e. tooth profiles for gears
P4, P5 and P6, indicate a deviation of the angle of tooth profile. Because the inclination of profile angles is almost identical for the analyzed teeth, and profile position deviation $\mathrm{f}_{\mathrm{H} \alpha}$ attains negative values, the profile angle increases and the tooth tip narrows. This is caused by polymer shrinkage during the cooling stage in the injection mold. As regards tooth trace of gear P5, its accuracy class is 10 for the left and the right tooth flank. It is the best accuracy class of all gears in the experiment. Tooth trace measurement results for P4 demonstrate accuracy class 12, whereas tooth trace for other gears is located outside accuracy class 12 . According to the analysis of the measurements of parameters describing gear pitch, radial runout and tooth thickness, measurement results placed the gears within accuracy class 12 . Tooth thickness variation parameter $R_{s}$ is particularly interesting. It defines the difference between the largest and the smallest gear tooth thickness, and tooth thickness determined by means of measuring length Wk over 3 teeth in the analyzed case. The chart shown in Fig. 5 indicates that gear P5 has the smallest tooth thickness variations, which has an effect on gear performance quality. In addition, tooth thickness values for all gears, determined by measuring length $\mathrm{Wk}$, are smaller than the nominal thickness specified in Table 1 (Fig. 6). The smallest comparable shrinkage is reported for gears P1, P2, P3, P5, while gears P4 have the highest shrinkage.

The present article also analyses of the topography of test gear teeth. The topography was presented for a single tooth of the gear (Fig. 3), and determined on the basis of the measurements of 9 profiles distributed evenly over a certain profile assessment interval (interval $\mathrm{L} \alpha$ defined in the standard, $11.91 \mathrm{~mm}$ ) and 7 tooth traces located within a relevant tooth trace assessment interval (interval $\mathrm{L} \beta$ defined in the standard, $15 \mathrm{~mm}$ ). The analysis of the charts reveals that gears $\mathrm{P} 1, \mathrm{P} 4$ and $\mathrm{P} 5$ feature topography which confirms a change in tooth profile angle, the char-

T a b l e 3. Gear accuracy class, as well as the classes of the profile and tooth trace, gear pitches, radial runout and tooth thickness variation [7] determined in the study

\begin{tabular}{|c|c|c|c|c|c|c|c|c|}
\hline \multirow{2}{*}{ Test gear } & \multicolumn{2}{|c|}{ Tooth profile } & \multicolumn{2}{|c|}{ Tooth trace } & \multicolumn{2}{|c|}{ Pitch } & \multirow{2}{*}{$\begin{array}{c}\text { Thickness } \\
\text { and runout } \\
\mathrm{F}_{\mathrm{r},} \mathrm{R}_{\mathrm{s}}\end{array}$} & \multirow{2}{*}{ Gear class } \\
\hline & Left & Right & Left & Right & Left & Right & & \\
\hline P1 & $\begin{array}{l}\gg \\
\mathrm{f}_{\mathrm{H} \alpha}\end{array}$ & $\begin{array}{c}\gg \\
\mathrm{f}_{\mathrm{H} \alpha^{\prime}}, \mathrm{F}_{\alpha} \\
\end{array}$ & $\begin{array}{c}12 \\
\mathrm{f}_{\mathrm{H} \beta^{\prime}} \mathrm{f}_{\mathrm{f} \beta}\end{array}$ & $\begin{array}{l}> \\
\mathrm{f}_{\mathrm{H} \beta}\end{array}$ & $\begin{array}{l}12 \\
\text { all } \\
\end{array}$ & $\begin{array}{l}12 \\
\text { all } \\
\end{array}$ & 12 & $\gg$ \\
\hline \multirow{2}{*}{ P2 } & $\gg$ & $\gg$ & $\gg$ & $>$ & 12 & 12 & \multirow{2}{*}{12} & \multirow{2}{*}{$\gg$} \\
\hline & $\mathrm{f}_{\mathrm{H} \alpha^{\prime}} \mathrm{F}_{\alpha}$ & $\mathrm{f}_{\mathrm{H} \alpha}$ & $\mathrm{F}_{\beta} \mathrm{f}_{\mathrm{f} \beta}$ & $\mathrm{f}_{\mathrm{H} \beta} \mathrm{F}_{\beta^{\prime}} \mathrm{f}_{\mathrm{f} \beta}$ & all & all & & \\
\hline P3 & $\begin{array}{l}10 \\
\mathrm{f}_{\mathrm{H} \alpha} \\
\end{array}$ & $\begin{array}{l}12 \\
\mathrm{f}_{\mathrm{H} \alpha}\end{array}$ & $\begin{array}{l}>> \\
f_{f \beta}\end{array}$ & $\begin{array}{l}12 \\
\mathrm{f}_{\mathrm{H} \beta} \\
\end{array}$ & $\begin{array}{l}12 \\
\text { all } \\
\end{array}$ & $\begin{array}{l}12 \\
\text { all } \\
\end{array}$ & 12 & $\gg$ \\
\hline P4 & $\begin{array}{c}>> \\
\mathrm{f}_{\mathrm{H} \alpha^{\prime}} \mathrm{F}_{\alpha}\end{array}$ & $\begin{array}{c}>> \\
\mathrm{f}_{\mathrm{H} \alpha^{\prime}}, \mathrm{F}_{\alpha}\end{array}$ & $\begin{array}{c}11 \\
\mathrm{f}_{\mathrm{H} \beta^{\prime}} \mathrm{F}_{\beta^{\prime}} \mathrm{f}_{\mathrm{f} \beta}\end{array}$ & $\begin{array}{l}12 \\
\mathrm{f}_{\mathrm{H} \beta}\end{array}$ & $\mathrm{f}_{\text {pmax }} \mathrm{F}_{\mathrm{p}}$ & $\begin{array}{l}12 \\
\text { all } \\
\end{array}$ & 12 & $\gg$ \\
\hline P5 & $\begin{array}{l}> \\
\mathrm{f}_{\mathrm{H} \alpha}\end{array}$ & $\begin{array}{l}\gg \\
\mathrm{f}_{\mathrm{H} \alpha}\end{array}$ & $\begin{array}{c}10 \\
\mathrm{f}_{\mathrm{H} \beta^{\prime}} \mathrm{F}_{\beta} \\
\end{array}$ & $\begin{array}{c}10 \\
\mathrm{f}_{\mathrm{H}^{\prime}}, \mathrm{F}_{\beta} \\
\end{array}$ & $\begin{array}{l}12 \\
\text { all } \\
\end{array}$ & $\begin{array}{l}12 \\
\text { all } \\
\end{array}$ & 12 & $\gg$ \\
\hline P6 & $\begin{array}{c}>> \\
\mathrm{f}_{\mathrm{H} \alpha^{\prime}} \mathrm{F}_{\alpha}\end{array}$ & $\begin{array}{c}\gg \\
\mathrm{f}_{\mathrm{H} \alpha^{\prime}}, \mathrm{F}_{\alpha}\end{array}$ & $\begin{array}{l}12 \\
\mathrm{f}_{\mathrm{f} \beta} \\
\end{array}$ & $\begin{array}{l}> \\
\mathrm{f}_{\mathrm{f} \beta}\end{array}$ & $\begin{array}{c}12 \\
\mathrm{f}_{\mathrm{pmax}}, \mathrm{f}_{\mathrm{umax}}, \mathrm{F}_{\mathrm{p}}\end{array}$ & $\begin{array}{c}12 \\
\mathrm{f}_{\mathrm{pmax}}, \mathrm{f}_{\mathrm{umax}}, \mathrm{F}_{\mathrm{p}}\end{array}$ & 12 & $\gg$ \\
\hline
\end{tabular}




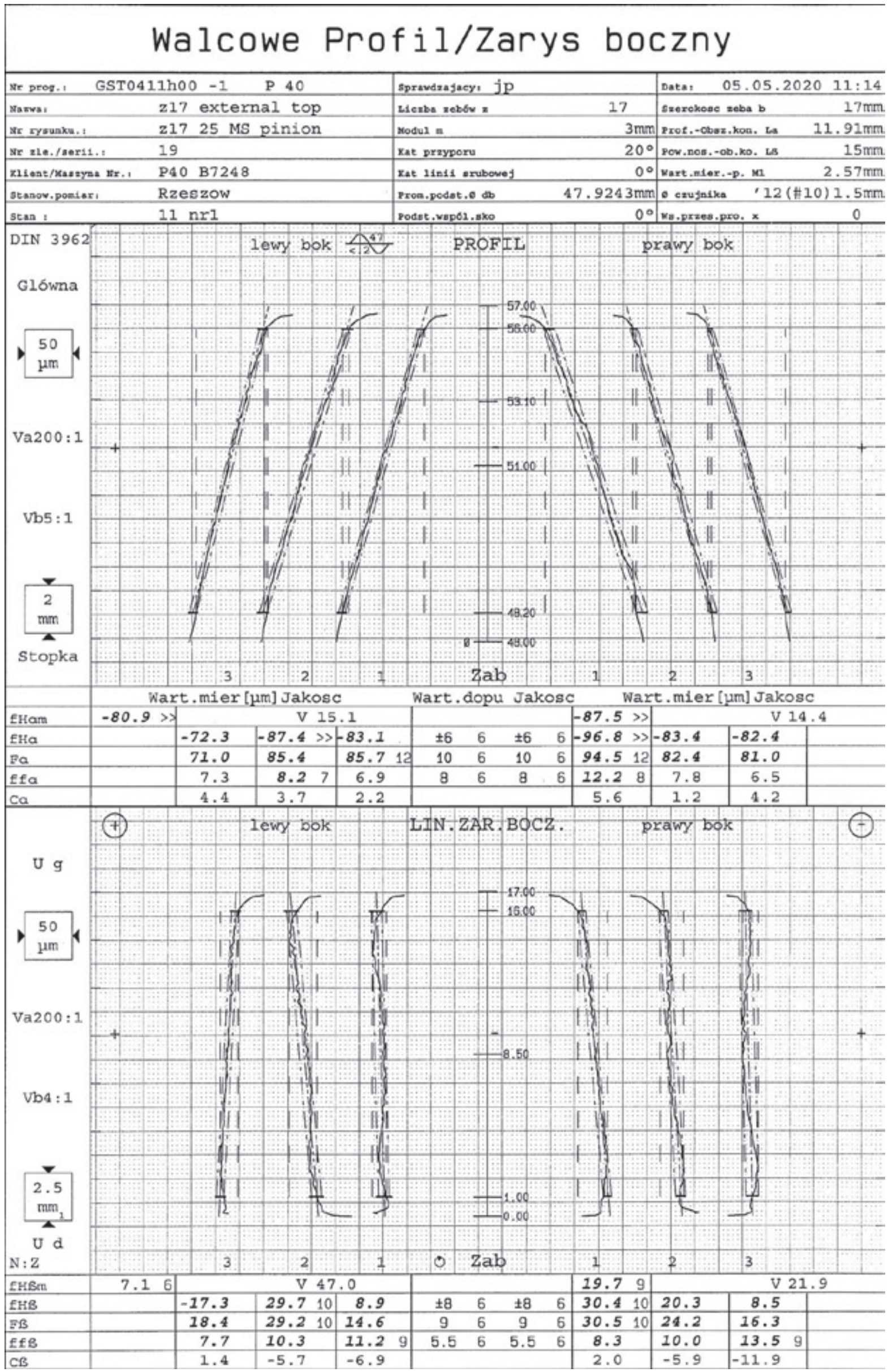

Fig. 2. P5 pinion (z17): tooth profile and tooth trace measurement results 


\section{Walcowe Topografia}

\begin{tabular}{|c|c|c|c|c|c|c|}
\hline the prog.: & \multicolumn{2}{|c|}{ GST0411h00 - 1 P 40} & \multicolumn{2}{|l|}{ Spraindzafacr: jp } & 05.05 .20 & $2011: 16$ \\
\hline \multicolumn{2}{|l|}{ Maža: } & z17 external top & \multicolumn{2}{|l|}{ Idezba zebser a } & Jaerakose zebs b & $17 \mathrm{~mm}$ \\
\hline \multicolumn{2}{|c|}{ Mr ryeunka.1 } & z17 25 MS pinion & \multicolumn{2}{|l|}{ nodul in } & Prot.-0osz. Kon. Wa & $11.91 \mathrm{~mm}$ \\
\hline \multicolumn{2}{|c|}{ SE 210.1 serili.t } & 19 & \multicolumn{2}{|l|}{ Kat przypors } & Pow. nos. -ob, ko, is & $15 \mathrm{~mm}$ \\
\hline \multicolumn{2}{|c|}{ xileat/Raszyan X:.: } & P40 37248 & \multicolumn{2}{|l|}{ Kat 1 inil geubovej } & Wart.nier.-p. K1 & $2.57 \mathrm{~mm}$ \\
\hline \multicolumn{2}{|c|}{ seanow,ponilas: } & Rzeszow & \multirow{2}{*}{$\begin{array}{l}\text { Proa, podat.o ab } \\
\text { Podat,wap51. ako }\end{array}$} & $47.9243 \mathrm{~mm}$ & D exujaika & 10) $1.5 \mathrm{~mm}$ \\
\hline \multicolumn{2}{|l|}{ Stan , } & $11 \mathrm{nr} 1$ & & $0^{\circ}$ & Ws.przes.pto. $x$ & 0 \\
\hline \multirow{2}{*}{$\frac{\Omega^{27}}{2}$} & Prawy & zarys boczny & Podat.wap51,ako & Lewy & zarys boczny & \\
\hline & & & $\mathrm{U}: \mathrm{g}:$ & & & \\
\hline
\end{tabular}

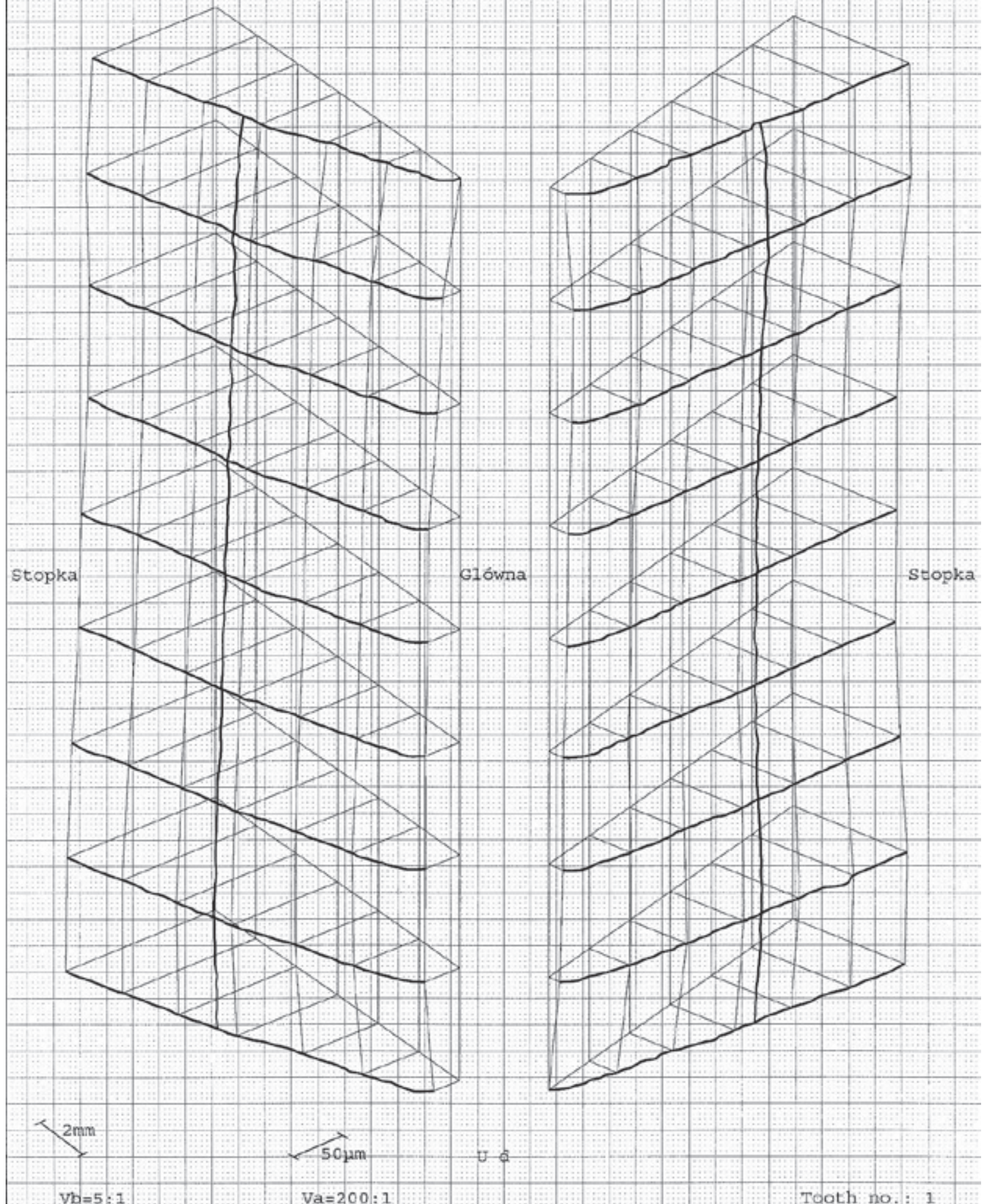

Fig. 3. P5 pinion (z17): tooth topography measurement results 


\section{Walcowe Podzialka}

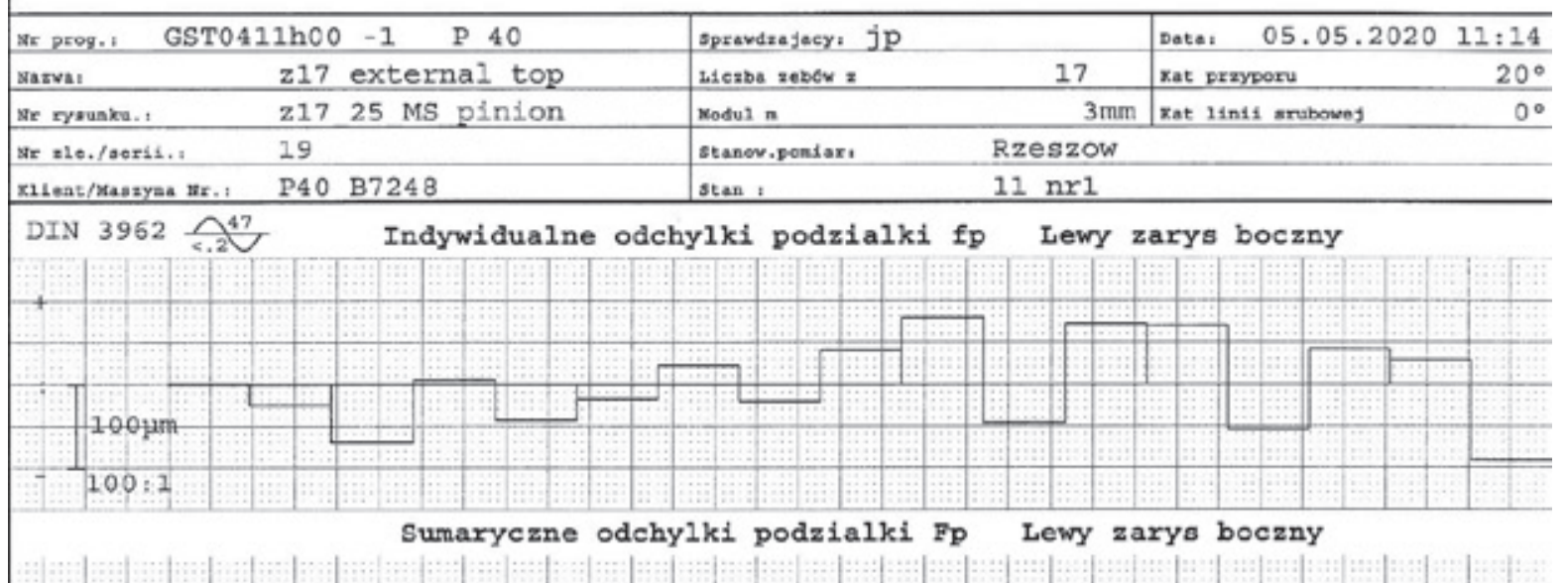
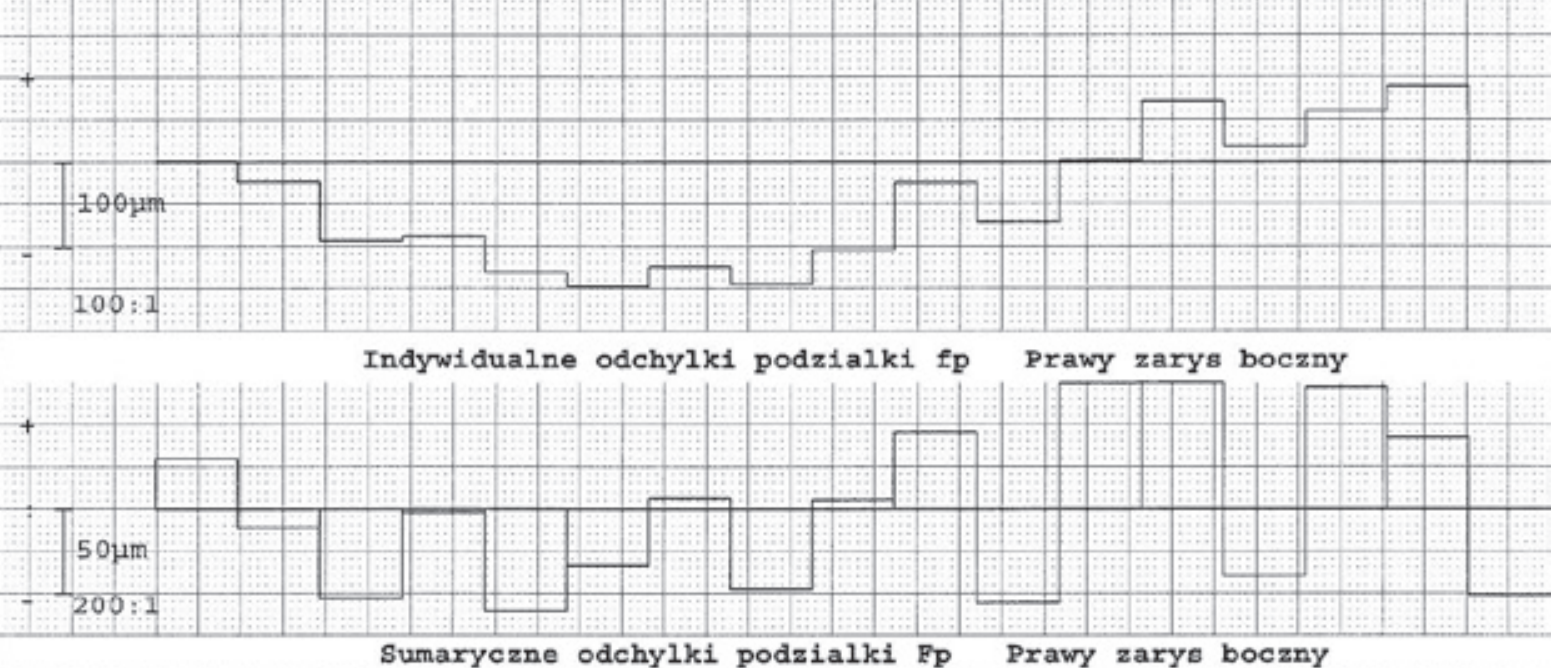

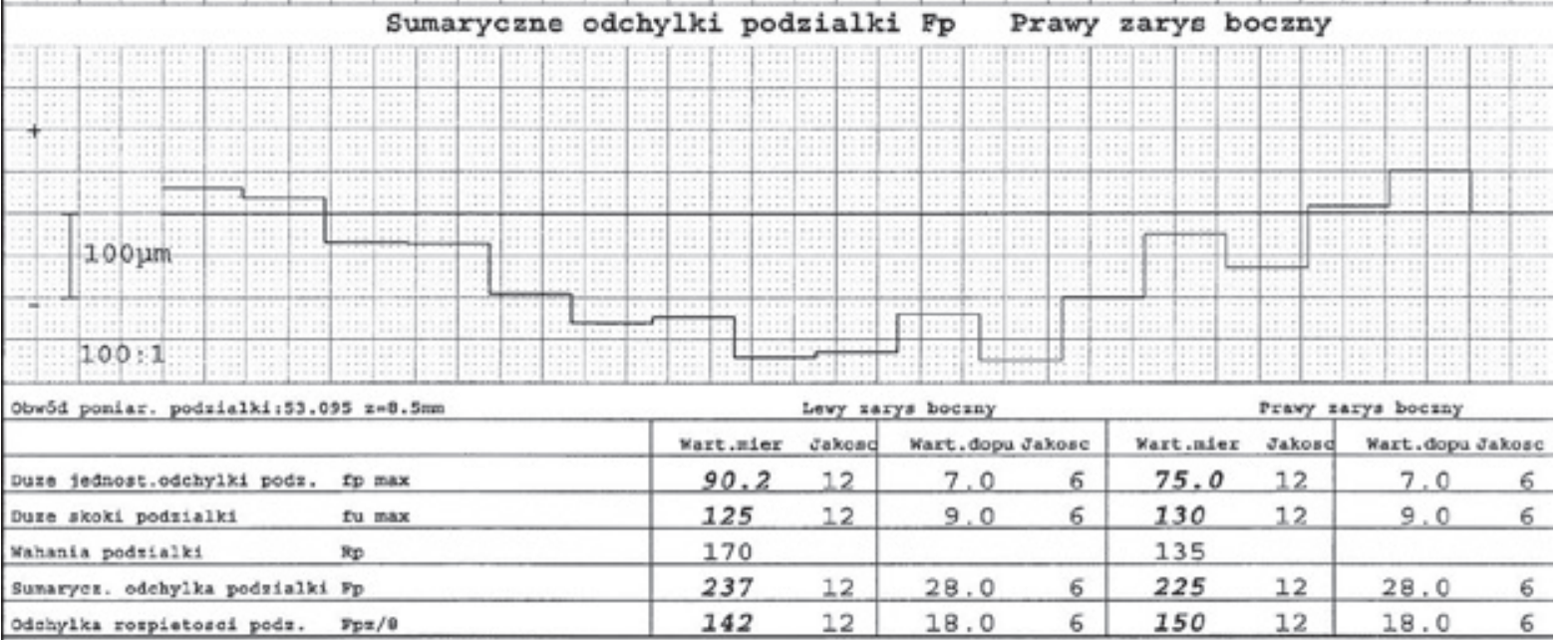

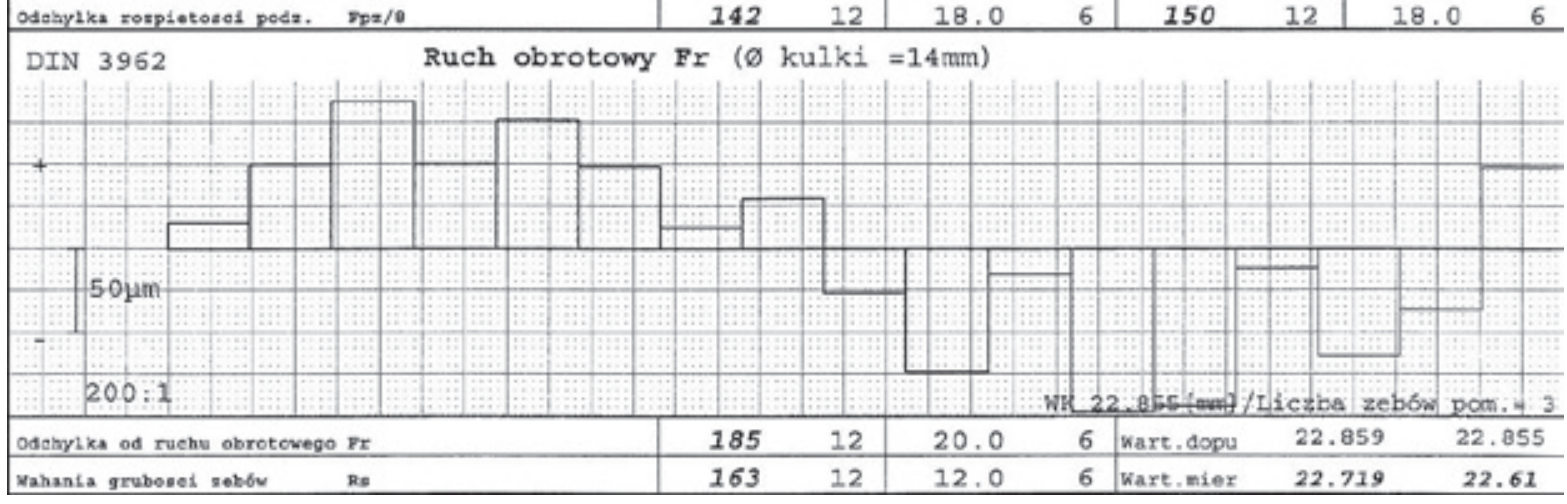

Fig. 4. P5 pinion (z17): pitch and tooth thickness measurement results 


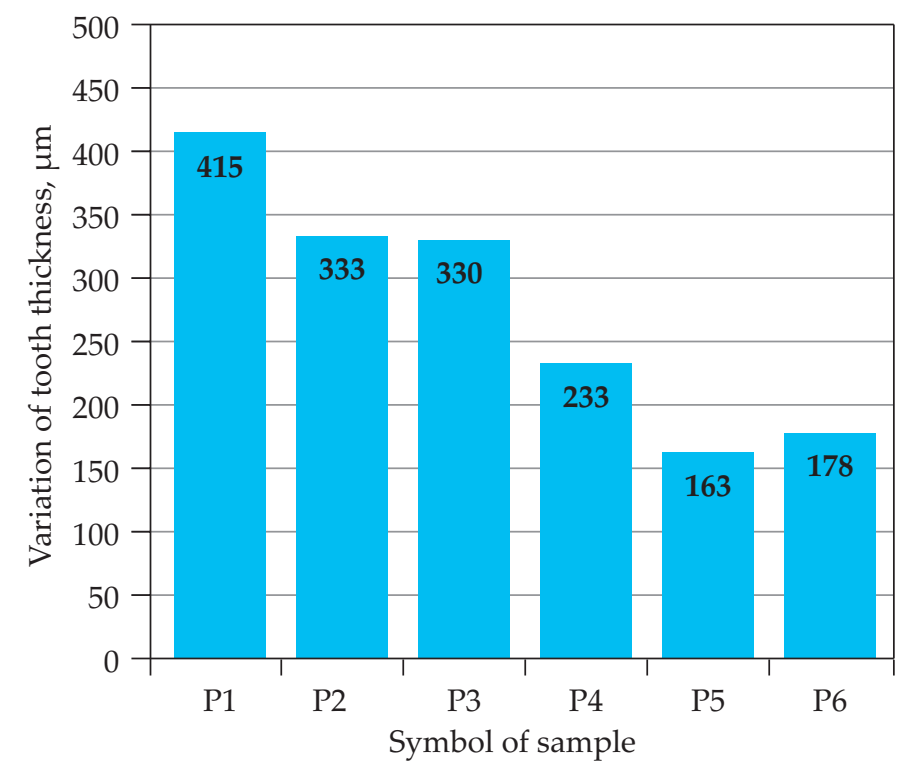

Fig. 5. A chart showing the variation of test gear tooth thickness $\left(R_{s}\right)$

acter of which is invariable on tooth flanks. Topographies of the teeth of all gears contain concavities. Gear P6 has a clear concavity on the right flank of the tooth (approx. $50 \mathrm{~mm}$ ), gears P1 and P2 have a clear concavity on the left flank of the tooth, while gear P3 has an even concavity on both tooth flanks.

\section{CONCLUSIONS}

On the basis of the results we may conclude that polymer gear P5 returned the best results, although all gears tested in this study were placed outside accuracy class 12 . In other cases, geometry tests of gear surfaces showed much inferior results. This may suggest either that injection parameters were poorly optimized or that the cooling time was too short. Unfortunately, the gears require additional processing by means of machining e.g. by gear shaving.

\section{REFERENCES}

[1] Pisula J.: Polimery 2019, 64, 353. http://dx.doi.org/10.14314/polimery.2019.5.6

[2] Budzik G., Dziubek T., Zaborniak M.: „Analiza dokładności geometrycznej prototypów kół zęba-

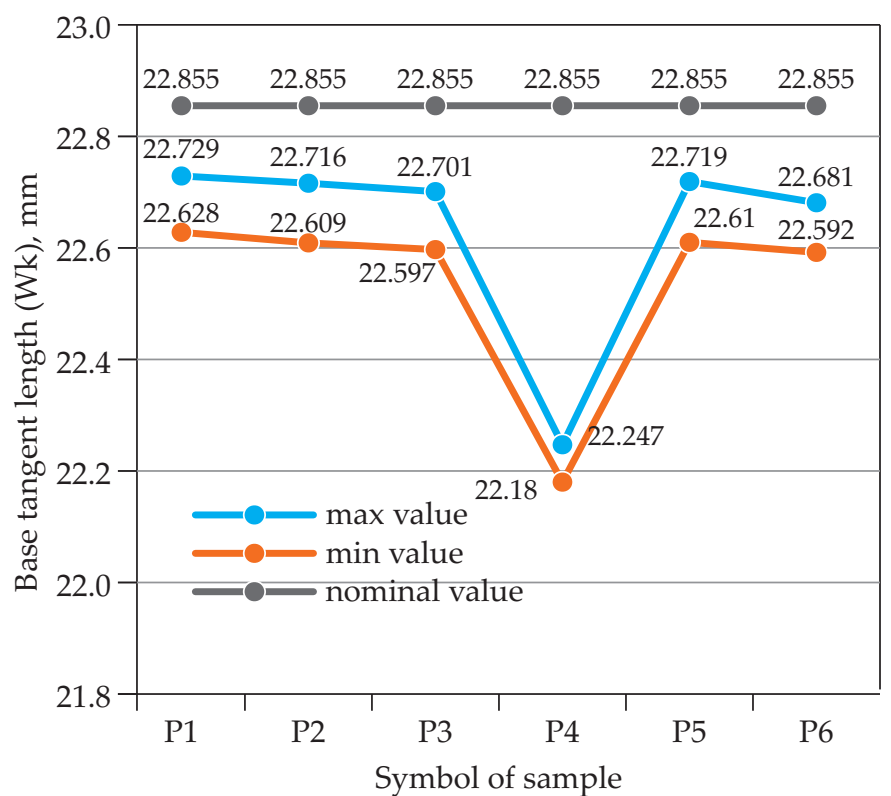

Fig. 6. A chart presenting test gear tooth fluctuations provided by means of measuring length $(\mathrm{Wk})$

tych z zastosowaniem współrzędnościowej techniki pomiarowej” in „Określenie chwilowego śladu styku przekładni zębatych z zastosowaniem metod szybkiego prototypowania", Oficyna Wydawnicza Politechniki Rzeszowskiej, 2011, pp. 131-148, ISBN 978-83-7199-686-3.

[3] Thirugnanam A., Sathish J., Rakesh L.: Middle East Journal of Scientific Research 2014, 20, 966. http://dx.doi.org/10.5829/idosi.mejsr.2014.20.08.114144

[4] Mao K., Li W., Hooke C., Walton D.: Wear 2009, 267, 639.

https://doi.org/10.1016/j.wear.2008.10.005

[5] Mao K., Langlois P., Hu Z. et al.: Wear 2015, 332-333, 822.

https://doi.org/10.1016/j.wear.2015.01.084

[6] Sobolak M., Połowniak P., Cieplak M. et al.: Polimery 2020, 65, 563.

http://dx.doi.org/10.14314/polimery.2020.7.9

[7] DIN 3962-1,2: 1978: Tolerances for cylindrical gear teeth. Part 1: Tolerances for deviations of individual parameters. Part 2: Tolerances for tooth trace deviation

Received 28 VIII 2020. 